\title{
THE DEVELOPMENT AND VALIDATION OF HPLC METHOD FOR QUANTIFICATION OF DL- $\alpha$-TOCOPHEROL IN QUINOA SEEDS (Chenopodium quinoa Willd.)
}

\author{
Sanja J. Popović ${ }^{1 *}$, Ljiljana M. Kostadinović ${ }^{1}$, Jovana S. Brkljača ${ }^{1}$, Jelena A. Krulj ${ }^{1}$, \\ Maja S. Manojlović ${ }^{2}$ Marija I. Bodroža Solarov ${ }^{1}$ \\ ${ }^{1}$ University of Novi Sad, Institute of Food Technology , Bulevar cara Lazara 1, 21000 Novi Sad, Serbia \\ ${ }^{2}$ University of Novi Sad, Faculty of Agriculture,Trg Dositeja Obradovića 8, 21000 Novi Sad, Serbia
}

${ }^{*}$ Corresponding author:

Phone: +381214853775

e-mail: sanja.popovic@fins.uns.ac.rs

\begin{abstract}
Aiming to achieve a precise method with easy application, this study presents the development and validation of a fast method for quantification of vitamin DL- $\alpha$-tocopherol in quinoa seeds. The methodology was based on an extraction procedure using ultrasonic bath and determination by normal-phase HPLC with UV-VIS detector. Validation parameters showed adequate linearity, relative standard deviations between 0.5 and $0.8 \% \quad(n=10)$, limits of detection and quantification were $3.0 \mathrm{ng} / \mathrm{mL}$ and $11.0 \mathrm{ng} / \mathrm{mL}$, respectively. Moreover, testing the robustness of the method suggested that it was not changeable with time or condition. The results showed that this method is accurate and simple and thus applicable in laboratories for determination of DL-atocopherol in quinoa seeds.
\end{abstract}

Key words: $D L-\alpha$-tocopherol, quinoa seed, HPLC

\section{INTRODUCTION}

In recent years, there has been a great interest in the relationship between plantbased nutrition and the prevention of human diseases caused by increased levels of radicals (Frias et al., 2005).

Vitamin $E$ is known as an essential micronutrient for maintaining the health and wellbeing of humans due to its antioxidant activities (Cadenas and Packer, 2002; Brigelius-Flohe and Galli, 2010). DL- $\alpha$-tocopherol, the form of vitamin $E$ that is preferentially absorbed and accumulated in humans, is a fat-soluble antioxidant that acts as a peroxyl radical scavengers preventing the propagation of free radicals in tissues. DL- $\alpha$-tocopherol reacts with free radicals thus forming a tocopheryl radical, which is subsequently reduced by a hydrogen donor and therefore returned to its reduced form (Traber and Stevens, 2011).
As it is fat-soluble, mentioned vitamin is incorporated into cell membranes, has a protective role in terms of oxidative damage and thus plays an important role in prevention of Alzheimer's disease and cancer (Tucker and Townsend, 2005).

While cereal grains are known to be good source of vitamin $E$, scientists strive towards finding alternative sources of vitamin $\mathrm{E}$ that can promote health. The pseudocereal quinoa (Chenopodium quinoa Willd.), which is native to the Andean regions of South America, has good nutritional profile and is considered as health-promoting food (Matiacevich et al., 2006). High nutritional value of quinoa seeds is related to the high protein content and wide range of minerals and vitamins (Fleming and Galwey, 1995). Koziol (1992) reported that quinoa contains more 
a-tocopherol than rice, barley and wheat (approximately $5.37 \mathrm{mg} / 100 \mathrm{~g}$ of DM).

Quinoa flour of excellent quality is obtained from quinoa seeds and nowadays widely used as a substitution for wheat flour, for instance, in bread, noodles, pasta and sweet biscuits (Valencia-Chamorro, 2003). Quinoa flour can also be extruded, ensuring food with physical, sensorial and nutritional qualities at an enviable level (Valencia-Chamorro, 2003).

The aim of this study was to develop and validate a rapid and accurate method for quantification of DL-a-tocopherol in quinoa seeds. Such study would contribute to further knowledge relating to the stability of this vitamin in different products obtained from quinoa seeds.

\section{MATERIALS AND METHODS}

\section{Quinoa seeds}

Ten genotypes of quinoa seeds (Chenopodium quinoa Willd.) were obtained from field experiment conducted in province Vojvodina (north Serbia).

\section{Extraction procedure}

Before extraction of DL-alpha-tocopherol, quinoa seeds were ground using 1095 Knifetec Sample Mill.

Extraction procedure was carried out taking care to protect DL-alpha-tocopherol from light and oxidising conditions. Methanol was used as an extraction solvent. Approximately $5 \mathrm{~g}$ of sample was kept in $30 \mathrm{~mL}$ of extraction solvent in the dark at room temperature during the period of $16 \mathrm{~h}$. Then it was sonicated in ultrasonic bath (VIMS elektrik, Loznica) for $40 \mathrm{~min}$. After filtering through the wide-pore filter paper, methanol was evaporated using a Rota-vapor at $28{ }^{\circ} \mathrm{C}$. Then $10 \mathrm{~mL}$ of $\mathrm{n}$-hexan was added and sonicated again for 20 min. n-hexan was subseqently evaporated using a Rotavapor at $28{ }^{\circ} \mathrm{C}$. The residue was dissolved in $1 \mathrm{~mL}$ of $\mathrm{n}$-hexan and filtered (PTFE filter, $0.2 \mu \mathrm{m}$ pore size) in vial prior to HPLC analysis.

\section{Reagents and standards}

DL-alpha-tocopherol (analytical standard, min. 99.9\%) for HPLC determination was obtained from Supelco Analytical, USA.
Methanol and n-hexan (HPLC grade) were purchased from Sigma-Aldrich.

Standard stock solution (concentration 1 $\mathrm{mg} / \mathrm{mL}$ ) was prepared by dissolving $10 \mathrm{mg}$ of DL-alpha-tocopherol standard in $10 \mathrm{~mL}$ of isopropanol and was kept at a temperature of $4{ }^{\circ} \mathrm{C}$ protected from light.

The working standard solutions chosen for the calibration curve were prepared by dissolving the stock standard solution in $\mathrm{n}$ hexan, in appropriate ratios, in order to obtain the following concentrations: 4, 10, 16, 22 and $28 \mu \mathrm{g} / \mathrm{mL}$. Dark volumetric flasks were kept protected from light at a temperature of $4{ }^{\circ} \mathrm{C}$ prior to HPLC analysis.

\section{HPLC analysis}

HPLC instrument was an Agilent 1200 system consisted of a UV-Visible detector (DAD), a binary pump, a vacuum degasser, an auto sampler. System control and data analysis were processed with Chemstation Software (Agilent Technologies). The chromatographic separation was performed on an Agilent column (Zorbax eclipse plus-C18, $1.8 \mu \mathrm{m}$ particle size, $100 \mathrm{~mm} \times 2.1 \mathrm{~mm}$ I.D.) kept at $25^{\circ} \mathrm{C}$. The mobile phase consisted of $100 \%$ n-hexan, using an isocratic elution procedure with a flow-rate of $0.3 \mathrm{~mL} / \mathrm{min}$ and a pressure of 105 bars. Five microliters of samples was injected onto the HPLC column. The total run time was $20 \mathrm{~min}$. The chromatogram was monitored at a wavelength of a $285 \mathrm{~nm}$ during the experiment. The compounds were identified by chromatographic comparisons with authentic standards and against UV spectra comparison using a DAD detector. Quantification was based on the signal response, using the method of standard addition.

\section{Method validation}

The validation of the HPLC method for determination of DL-alpha-tocopherol in quinoa seeds was conducted by defining various validation parameters: linearity range, accuracy, precision and limits of detection (LOD) and quantification (LOQ).

Furthermore, robustness and specificity of the method were also investigated. The peaks were identified by their retention times, comparing the UV-Visible spectra and spiking with standards. Quantification has been done using an external standard 
curve with five points. The linearity range was evaluated by plotting the peak area corresponding to analyte, as a function of the concentration introduced.

Precision of the method was determined under different circumstances, namely repeatability conditions, where independent experiments were carried out on the same day by the same operator using the same instrumentation (intra-day variation study), and intermediate conditions where the experiments were repeated on different days (inter-day variation study).

Accuracy was determined from the recovery rate at three concentration levels.

The limit of detection (LOD) and limit of quantification (LOQ) were relevant in the frame of this work, since the scope of the method was the determination of DL- $\alpha$ tocopherol in quinoa seeds, due to relatively low content of this vitamin.

\section{Data Analysis}

The differences were considered to be significant when $p<0.05$, and the data were analyzed using the software Statistica software version 12 (StatSoft inc., 2013).

\section{RESULTS AND DISCUSSION}

\section{Linearity of calibration curve}

Linearity of calibration curve was evaluated by the coefficient of determination $\left(R^{2}\right)$ using linear regression analysis, testing series of six injections of five standard solutions of DL- $\alpha$-tocopherol: 4, 10, 16, 22 and $28 \mu \mathrm{g} / \mathrm{mL}$ (Fig. 1). The standard solutions were tested under above described chromatographic conditions. Calibration curve was constructed by linear regression of the peak area $(Y)$ versus the concentration $(X)$. Calibration curve showed good linearity $\left(R^{2}=0.9994\right)$ of the DAD signal at $285 \mathrm{~nm}$ over a mentioned range of concentrations. The linear regression equation was as follows: $y=5.6882 x-3.3233$.

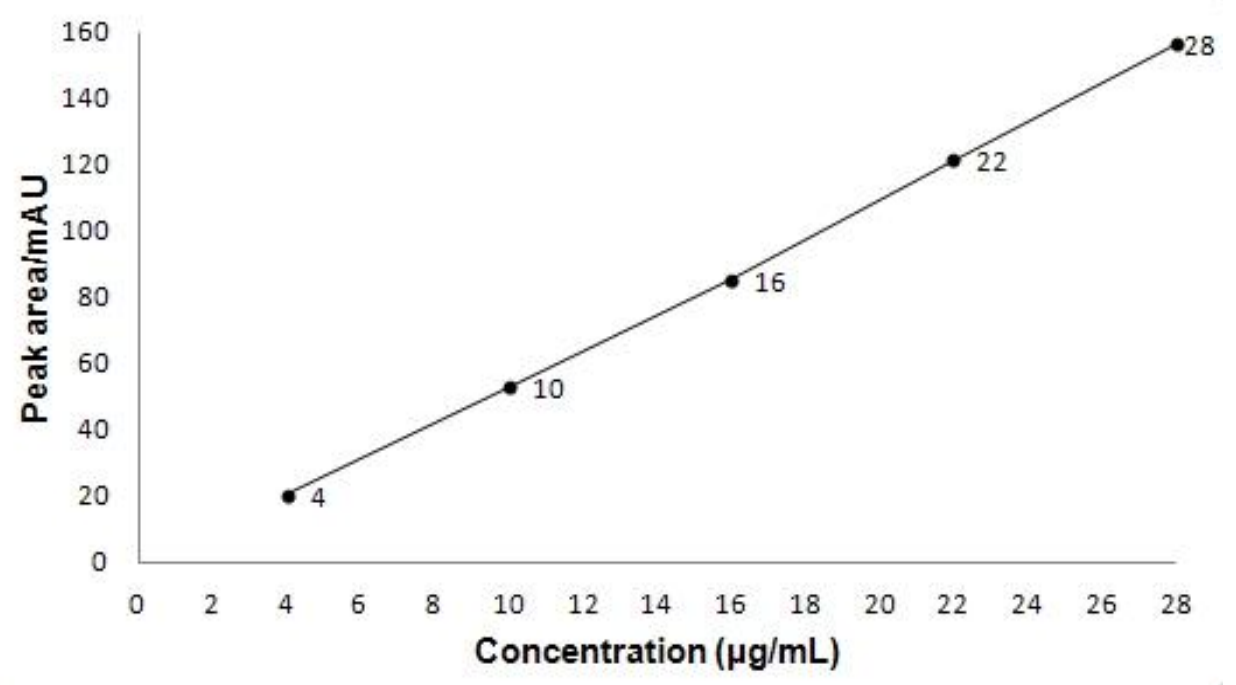

Figure 1. Calibration curve of DL- $\alpha$-tocopherol

\section{Recovery and precision}

\section{Table 1.}

Recovery and precision of the method

\begin{tabular}{|c|c|c|c|c|c|c|}
\hline 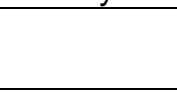 & $\begin{array}{c}\text { Initial } \\
(\mu \mathrm{g} / \mathrm{mL})\end{array}$ & $\begin{array}{c}\text { Added } \\
(\mu \mathrm{g} / \mathrm{mL})\end{array}$ & $\begin{array}{c}\text { Found } \\
(\mu \mathrm{g} / \mathrm{mL})\end{array}$ & $\begin{array}{c}\text { Recovery } \\
\text { (\%) }\end{array}$ & \multicolumn{2}{|c|}{$\begin{array}{l}\text { RSD } \\
(\%)\end{array}$} \\
\hline & & & & & Intra-day & Inter-day \\
\hline Sample 1 & 37.47 & 4.00 & 4.2 & 105.0 & $0.5^{\mathrm{a}}$ & $1.2^{\mathrm{a}}$ \\
\hline Sample 2 & 37.47 & 8.00 & 7.7 & 96.25 & $0.7^{\mathrm{a}}$ & $1.5^{\mathrm{a}}$ \\
\hline Sample 3 & 37.47 & 12.0 & 12.8 & 106.7 & $0.8^{\mathrm{a}}$ & $0.9^{\mathrm{a}}$ \\
\hline
\end{tabular}


Aim of the recovery study was to monitor the presence of matrix effects and to check the accuracy of the developed method. The accuracy of the analytical method was determined by spiking a known amount of DL-a-tocopherol standards into the samples of quinoa seeds and analyzing the percentage of recovery. Standard solutions were prepared in triplicate at three different levels (40\%, 80\% and $120 \%$ ) of DL-a-tocopherol working standard (concentration $10 \mu \mathrm{g} / \mathrm{mL}$ ). Each standard solution was injected six times. Recovery mean values for samples were within the $96.25 \%$ and $106.7 \%$ range, indicating good accuracy of the developed method (Table 1).

The precision of the method was expressed as the percentage of relative standard deviation (RSD\%). In intra-day variation study ten injections of each of three standard solutions (concentrations $4.00 \mu \mathrm{g} / \mathrm{mL}$, $8.00 \mu \mathrm{g} / \mathrm{mL}$ and $12.0 \mu \mathrm{g} / \mathrm{mL}$ ) were done three times per day (in the morning, afternoon and evening). In inter-day variation study, ten injections of the same three standard solutions were done once a day on three different days. The relative standard deviations ranged between $0.5 \%$ and $0.8 \%$ within intra-day variation study. Likewise the relative standard deviations were between $0.9 \%$ and $1.5 \%$ within inter-day variation study. Analysis of variance (ANOVA) showed that there were no significant differences ( $p>0.05)$ between samples in intra-day and inter-day variation studies (Table 1).

The obtained results indicated that the proposed HPLC method has an acceptable precision of DL- $\alpha$-tocopherol determination. Any interference was not present in the analyzed quinoa seeds.

\section{Detection limit and quantification limit}

The limits of detection (LOD) and quantification (LOQ) were defined as the lowest concentration of each compound, over five replicate injections with real sample extracts, which gave an average signal-tonoise ratio greater than 3 or 10 , respecttively (Cruz and Casal, 2013). The LOD and LOQ in this study were $3 \mathrm{ng} / \mathrm{mL}$ and $11 \mathrm{ng} / \mathrm{mL}$ of DL- $\alpha$-tocopherol, respectively.
These values indicated that investigated HPLC method is sensitive to quantify DLa-tocopherol in quinoa seeds.

\section{Specificity}

Specificity of the chromatographic method is the ability of the method to accurately measure the analyte response in the presence of all potential sample components (Shabir, 2003). The response of the analyte in quinoa seeds containing the analyte and all potential sample components (vitamins, lipids, minerals, proteins, etc.) is compared with the response of a solution containing only the analyte (Figure 2 and Figure 3).

Chromatogram of quinoa seeds' extract showed no peaks in the region in which DL-a-tocopherol eluted, indicating specificity of the method against interference. This observation is relevant for determination of DL- $\alpha$-tocopherol, since it is present in food in micro amounts.

\section{Robustness}

The robustness of the method was examined by conducting the analysis under different chromatographic conditions, such as changes in HPLC flow rate or mobile phase solvent. Moreover, the time of ultrasonic processing after the extraction step was varied. Obtained results showed that the investigated varied parameters did not affect the retention time as well as the peak parameters. When comparing the peak of DL-a-tocopherol from standard solution with the peak of DL-a-tocopherol from extract of quinoa seeds, it can be noted that there was no modification in peak profile. This fact suggests that the method did not change with time or conditions.

\section{CONCLUSIONS}

This study focused on developing a method for accurate determination of the DLa-tocopherol in quinoa seeds with adequate sensitivity, precision and accuracy, while being rapid and requiring only standard chromatographic equipment available to most analytical laboratories. The proposed method is suitable for DL-alphatocopherol quantification, enabling analysis of more samples in a short period of time. This method is thus suitable for routine a- 


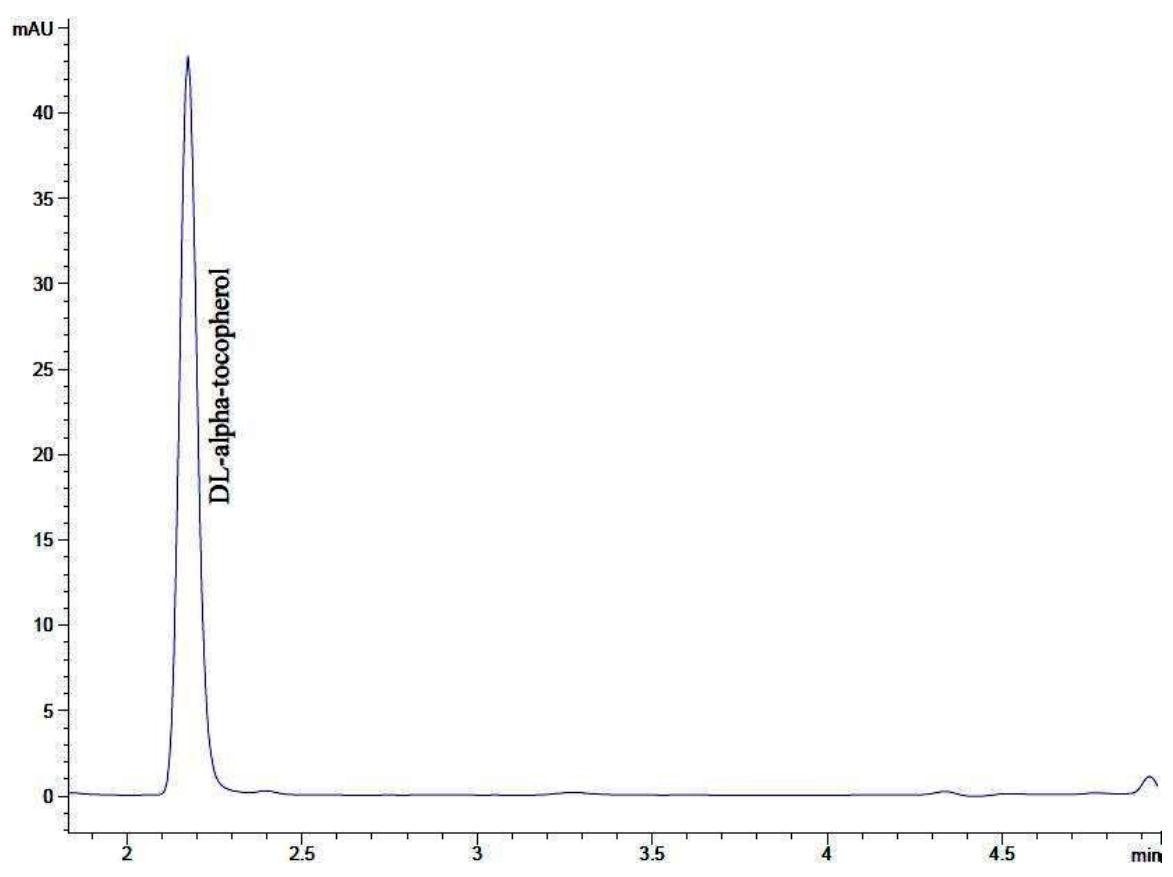

Figure 2. HPLC chromatogram corresponding to DL-a-tocopherol standard solution (concentration $28 \mu \mathrm{g} / \mathrm{ml}$ )

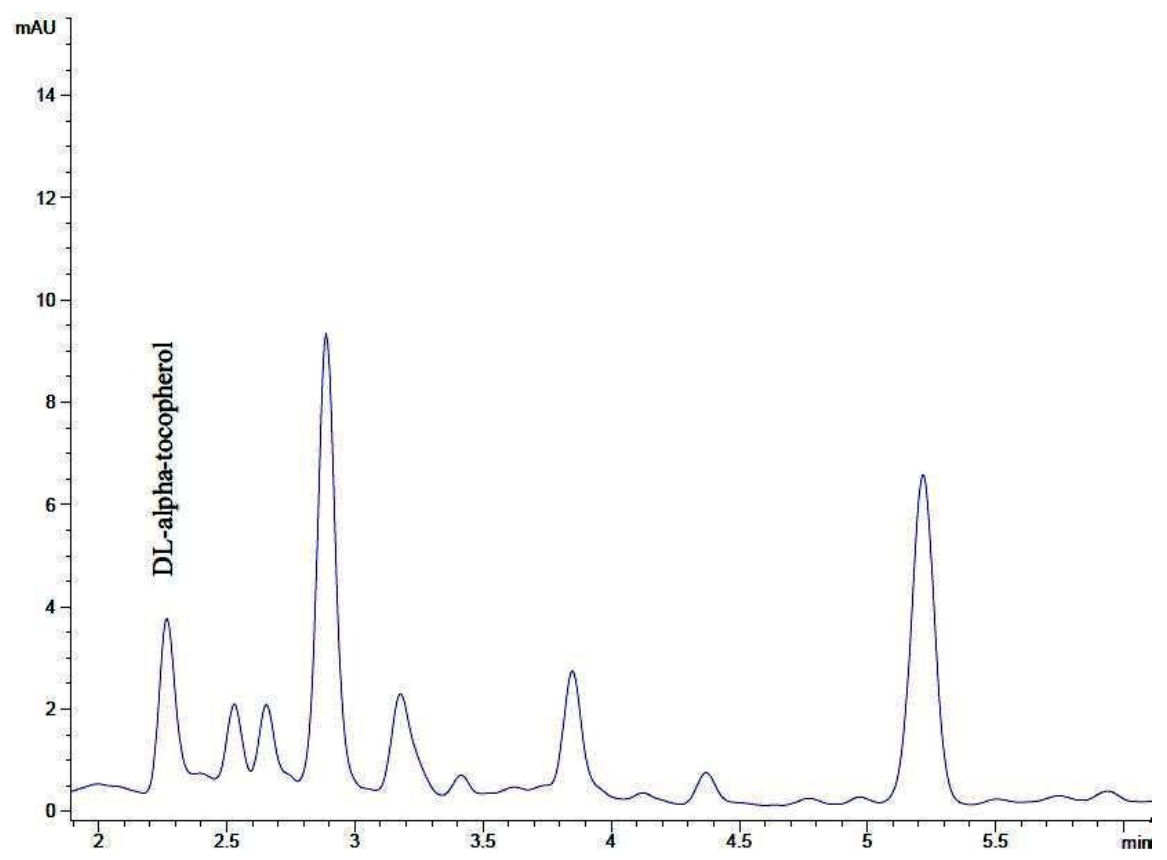

Figure 3. HPLC chromatogram corresponding to extract of quinoa seeds

nalyses and can be used for quinoa seeds quality control or other related studies.

\section{ACKNOWLEDGEMENTS}

The paper is a part of the research work on the project III-46005 and TR 31027 financed by the Ministry of Education,
Science and Technological Development of the Republic of Serbia.

\section{REFERENCES}

1. Brigelius-Flohe, R., Galli, F. (2010). Vitamin E: A vitamin still awaiting the detection of its bio- 
logical function. Molecular Nutrition \& Food Research, 54 (5), 583-587.

2. Cadenas, E., Packer, L. (2002). Handbook of antioxidants, Marcel Dekker, New York.

3. Cruz, R, Casal, S. (2013). Validation of a fast and accurate chromatographic method for detailed quantification of vitamin $\mathrm{E}$ in green leafy vegetables. Food Chemistry, 141 (2), 11751180.

4. Fleming, J. E., Galwey, N. W. (1995). Quinoa (Chenopodium quinoa). In: Cereals and Pseudocereals. Eds. J. T. Williams, Champam \& Hall, London, pp. 3-83.

5. Frias, J., Miranda, M. L., Doblado, R., VidalValverde, C. (2005). Effect of germination and fermentation on the antioxidant vitamin content and antioxidant capacity of Lupinus albus L. var. Multolupa. Food Chemistry, 92 (2), 211220.

6. Koziol, M. J. (1992). Chemical composition and nutritional evaluation of quinoa (Chenopodium quinoa Willd). Journal of Food Composition Analysis, 5, 35-68.

7. Matiacevich, S. B., Castellión, M. L., Maldonado, S. B., Buera, M. P. (2006). Waterdepen- dent thermal transitions in quinoa embryos. Thermochimica Acta, 448, 117-122.

8. Shabir, G. A. (2003). Validation of high-performance liquid chromatography methods for pharmaceutical analysis: Understanding the differences and similarities between validation requirements of the US Food and Drug Administration, the US Pharmacopeia and the International Conference on Harmonization. Journal of Chromatography A, 987 (1-2), 57-66.

9. STATISTICA (Data Analysis Software System) (2013). v.12.0. Stat-Soft, Inc, USA (www. statsoft.com).

10. Traber, M.G., Stevens, J.F. (2011). Free Radical Biology and Medicine - Vitamins C and $E$ : Beneficial effects from a mechanistic perspective. Free Radical Biology and Medicine, 51 (5), 1000-13.

11. Tucker, J. M., Townsend, D. M. (2005). Alphatocopherol: roles in prevention and therapy of human disease. Biomedicine \& Pharmacotherapy, 59, 380-387.

12. Valencia-Chamorro, S. A. (2003). Quinoa. In: Encyclopedia of Food Science and Nutrition (Vol. 8). Eds. B. Cabalero, Academic Press, Amsterdam, pp. 4895-4902.

\title{
РАЗВОЈ И ВАЛИДАЦИЈА МЕТОДЕ ЗА ОДРЕЪИВАЊЕ ДЛ-व-ТОКОФЕРОЛА У СЕМЕНУ КИНОЕ (Chenopodium quinoa Willd.)
}

\author{
Сања Ј. Поповић ${ }^{1}$, Љиљана М. Костадиновић ${ }^{1}$, Јована С. Бркљача ${ }^{1}$, Јелена А. Круљ ${ }^{1}$, \\ Маја С. Манојловић ${ }^{2}$, Марија И. Бодрожа Соларов \\ ${ }^{1}$ Универзитет у Новом Саду, Научни институт за прехрамбене технологије, \\ Булевар цара Лазара 1, 21000 Нови Сад, Србија \\ ${ }^{2}$ Универзитет у Новом Саду, Пољопривредни фракултет, Трг Доситеја Обрадовића 8, \\ 21000 Нови Сад, Србија
}

Сажетак: У овом раду је развијена и валидирана HPLC метода за рутинско одређивање

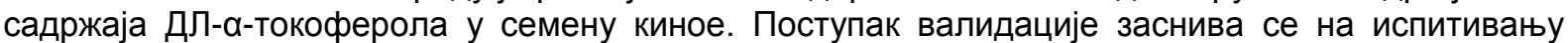
следећих параметара: линеарност, тачност, прецизност, граница детекције и граница квантифрикације, робусност и специфичност методе. Развијена метода се базира на екстракцији витамина ДЛ-а-токоферола применом ултразвучног купатила и метанола и хексана као екстракционих растварача. Нормално-фразна хроматографија под високим притиском са UV-VIS детектором коришћена је за детектовање испитиване супстанце. Метода је показала адекватну линеарност, док је релативна стандардна девијација износила између 0,5 и 0,8\% (n=10). Осетљивост методе испитана је одређивањем границе детекције и границе квантификације које су износиле $3,0 \mathrm{ng} / \mathrm{mL}$ и $11,0 \mathrm{ng} / \mathrm{mL}$. Такође, тестирањем робустности методе установљено је да метода није променљива при малим варијацијама параметара методе. Резултати су показали да је метода једноставна и тачна, и стога применљива у лабораторијама за одређивање садржаја ДЛ-а-токоферола у семену киное.

Кључне речи: ДЛ- $\alpha-$-окофрерол, семе киное, HPLC 